\title{
Karakter DAS Kambang Berdasarkan Analisis Morfometri dan Aspek Biofisik
}

\author{
Harisagustinawati ${ }^{1 *}$, Aswandi ${ }^{2}$, Sunarti $^{3}$ \\ 1,2,3 Program Studi Magister Ilmu Lingkungan, Pascasarjana Universitas Jambi \\ Jl. Arif Rahman Hakim, Telanaipura, Kota Jambi \\ *correspondence e-mail: harisagustinawati@gmail.com, gharisa @ yahoo.co.id
}

\begin{abstract}
Watershed (river basin) is a hydrological unit. DAS holds water, distributes water through a channel system from upstream to downstream, and ends in a body of water in the form of a lake or sea. Watershed is also an ecosystem, where the elements of organisms and the biophysical environment and chemical elements interact dynamically and in which there is a balance. DAS is seen as a unit of territorial unity where rainwater collects into a river to become a river flow. The factors that influence the characteristics of the watershed are morphometric factors and the biophysical aspects of the watershed. Watershed morphometry is a quantitative measure of the natural characteristics of the watershed, namely the geomorphological aspects of an area. This characteristic is related to the process of draining (drainage) of rainwater that falls in the watershed including the shape of the watershed, the area of the watershed, the density of the river (drainage), and the flow pattern. River flow is greatly influenced by the biophysical conditions of the Kambang watershed. Analysis of the biophysical conditions of the Kambang watershed includes analysis of soil types, land use, topographic conditions including slopes and contours, as well as the quality of Kambang river water. Considering the strategic designation of the Kambang watershed should be aligned with the watershed character.
\end{abstract}

Keywords: Watershed (river basin), DAS Kambang, Watershed morphometry, biophysical conditions of the Kambang watershed

\section{Pendahuluan}

Menurut UU No.7 Tahun 2004 tentang sumber daya air, Daerah Aliran Sungai atau yang selanjutnya disingkat DAS adalah suatu wilayah daratan yang merupakan satu kesatuan dengan sungai dan anak-anak sungainya, yang berfungsi menampung, menyimpan, dan mengalirkan air yang berasal dari curah hujan ke danau atau laut secara alami, yang batas di darat merupakan pemisah topografis dan batas di laut sampai dengan daerah perairan yang masih terpengaruh aktivitas daratan. Berdasarkan UU tersebut Ditjen Tata Ruang dan Pengembangan Wilayah Tahun 2002, DAS didefinisikan sebagai suatu daerah mempunyai bentuk dan sifat alam tertentu, merupakan satu kesatuan dengan sungai dan anak sungai yang melalui daerah tersebut.

Pengertian DAS sepadan dengan istilah dalam bahasa Inggris drainage basin, drainage area, atau river basin. Sehingga batas DAS merupakan garis bayangan sepanjang punggung pegunungan atau tebing/bukit yang memisahkan sistim aliran yang satu dari yang lainnya. Dari pengertian ini suatu DAS terdiri atas dua bagian utama daerah tadah (catchment area) yang membentuk daerah hulu dan daerah penyaluran air yang berada di bawah daerah tadah (Fuady ; 2013).

Dari definisi tersebut, dapat dikemukakan bahwa DAS merupakan satu kesatuan hidrologi. DAS menampung air, mendistribusikan air lewat suatu sistem saluran dari hulu ke hilir, dan berakhir di suatu badan air berupa danau atau laut. DAS juga merupakan ekosistem, dimana unsur organisme dan lingkungan biofisik serta unsur kimia berinteraksi secara dinamis dan di dalamnya terdapat keseimbangan. DAS dipandang sebagai suatu unit kesatuan wilayah tempat air hujan berkumpul ke sungai menjadi aliran sungai. Faktor yang mempengaruhi karakteristik DAS adalah faktor morfometri dan aspek biofisik DAS.

Morfometri DAS merupakan ukuran kuantitatif karakteristik alami DAS yaitu aspek geomorfologi suatu daerah. Karakteristik ini terkait dengan proses pengaliran (drainase) air hujan yang jatuh di dalam DAS diantaranya bentuk DAS, luas DAS, kerapatan sungai (drainase), dan pola aliran.

Biofisik DAS merupakan faktor yang akan mempengaruhi output dari proses terjadinya siklus hidrologi dalam suatu DAS sehingga aliran sungai sangat dipengaruhi oleh kondisi biofisik DAS. Analisis kondisi biofisik DAS meliputi analisis jenis tanah, tata guna lahan, kondisi topografi yang mencakup kemiringan lereng dan kontur, serta kualitas air sungai.

Daerah Aliran Sungai (DAS) Kambang dengan panjang sungai utama 4,304 Km dan luas $488 \mathrm{Ha}$ (empat ratus delapan puluh delapan hektar dan mempunyai sistem drainase dengan wilayah pelayanan meliputi: kelurahan Buluran Kenali, kelurahan Pematang Sulur, kelurahan Telanaipura, kelurahan Simpang IV Sipin, kelurahan Beliung, dan kelurahan Simpang III Sipin (Lampiran Perda No 9 Tahun 2013 RTRW Kota Jambi, 2013-2030).

Pembangunan Kota Jambi menyebabkan DAS Kambang dimanfaatkan untuk berbagai macam peruntukan. Selain sebagai pusat ibu kota, wilayah yang masuk dalam DAS Kambang juga merupakan pusat pendidikan, ekonomi, dan keagamaan. Peruntukan DAS Kambang yang strategis sebaiknya diselaraskan dengan karakter DAS Kambang. Penelitian ini bertujuan untuk menganalisis morfometri dan aspek biofisik DAS Kambang sehingga dapat diketahui karakteristik DAS Kambang.

\section{Metode Penelitian}

Penelitian ini dilaksanakan di Kota Jambi dengan fokus penelitian pada salah satu Daerah Aliran Sungai (DAS), yaitu DAS Kambang. Penelitian ini merupakan peneitian kualitatif deskriptif yang akan menyajikan gambaran lengkap tentang fenomena yang diteliti.

Data primer didapat dari observasi dan dokumentasi lapangan untuk mendapatkan kondisi eksisting DAS 
Kambang, wawancara, serta responden sedangkan data sekunder didapat dari instansi terkait seperti yaitu

1. Data DAS Kambang, berupa peta dan dokumentasi terkait dari Bappeda Provinsi Jambi dan PUPR Kota Jambi. Data ini disinkronkan dengan kondisi yang ada di lapangan.

2. Kualitas air dari DLH Kota Jambi

3. Peta jenis tanah dari BBSDLP Kementrian Pertanian Provinsi Jambi

Analisis data sekunder berupa peta menggunakan software Arc Gis. sedangkan data lain ditampilkan dalam bentuk tabel kemudian dianalisis deskriptif kualitatif.

\section{Hasil dan Pembahasan}

\subsection{Morfometri DAS Kambang}

Morfometri DAS merupakan ukuran kuantitatif karakteristik alami DAS yaitu aspek geomorfologi suatu daerah. Karakteristik ini terkait dengan proses pengaliran (drainase) air hujan yang jatuh di dalam DAS diantaranya bentuk DAS, luas DAS, kerapatan sungai (drainase), dan pola aliran.

\subsubsection{Bentuk DAS}

DAS Kambang memiliki bentuk memanjang (long watershed) yang dapat dilihat dari peta adminsitrasi DAS Kambang (Gambar 1.). Bentuk DAS memanjang dan sempit pada DAS Kambang akan cenderung menghasilkan laju aliran permukaan yang lebih kecil (Andini, 2019). Kondisi tersebut perlu diwaspadai pada saat hujan berintensitas lebat dengan durasi yang lama. Dengan kondisi yang demikian, DAS Kambang tidak menjadi daerah yang rawan banjir, tetapi jika terjadi cuaca ekstrim seperti hujan lebat akan menimbulkan genangan air di beberapa titik sehingga berpotensi menimbulkan banjir dengan waktu yang relatif lama.

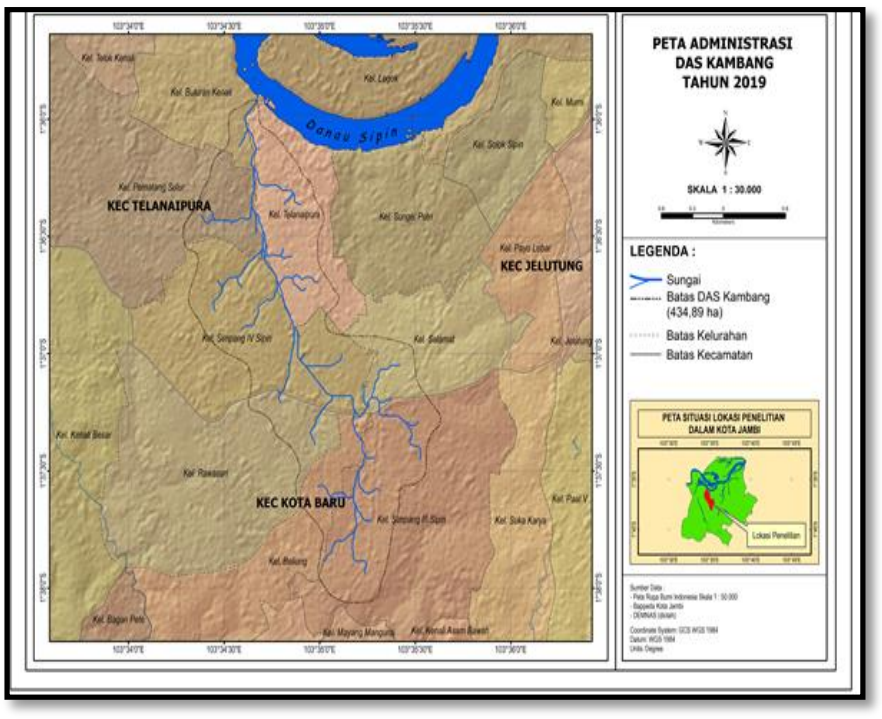

Gambar 1. Peta Administrasi DAS Kambang

\subsubsection{Luas DAS}

Berdasarkan hasil analisis spasial menggunakan software Arc GIS, DAS Kambang memiliki luas 434,89 Ha dan panjang sungai utama 4,6 Km serta total panjang sungai keseluruhan adalah 12,68 Km. DAS Kambang lebih tepat digolongkan sebagai DAS kecil karena luasnya $<500$ ha. Luas DAS nantinya akan mempengaruhi pemilihan metode perkiraan laju aliran puncak.

\subsubsection{Kerapatan Sungai (Drainase)}

Kerapatan sungai yang dimaksudkan adalah rasio (perbandingan) jumlah panjang sungai dalam $(\mathrm{km})$ terhadap luas Daerah Aliran Sungai. Hasil perhitungan untuk mengetahui kerapatan sungai pada DAS Kambang didapat berdasarkan indeks kerapatan aliran sungai berikut :

$$
\begin{aligned}
\operatorname{Dd} & =\frac{\mathrm{L}}{\mathrm{A}} \\
& =\frac{12,68}{4,3489} \\
& =2,91 \mathrm{~km} / \mathrm{km}^{2}
\end{aligned}
$$

Hasil perhitungan kerapatan sungai menunjukkan bahwa indeks kerapatan sungai adalah $2,91 \mathrm{~km} / \mathrm{km}^{2}$ sehingga DAS Kambang mempunyai kerapatan drainase tergolong sedang dimana untuk kategori ini memiliki rentang nilai 0,25 $10 \mathrm{~km} / \mathrm{km}^{2}$. Nilai ini bahkan mendekati kategori rendah $(<5$ $\mathrm{km} / \mathrm{km}^{2}$ ). Nilai kerapatan drainase yang rendah menunjukkan kerapatan aliran yang relatif rendah sehingga respon aliran permukaan lambat (Pingaleet al., 2012; Gebreet al., 2015). DAS Kambang dapat dikategorikan DAS rawan terjadi genangan. Jika terjadi genangan (banjir) maka cenderung terjadi dalam waktu yang cukup lama.

\subsubsection{Pola Aliran}

Pola aliran DAS Kambang adalah dendritik (Gambar 1) karena pola aliran yang mirip sebuah struktur pohon dengan cabang-cabangnya, mengalir ke semua arah dan akhirnya menyatu di induk sungai. Sehingga umumnya terjadi peningkatan aliran pada titik pertemuan anak-anak sungai.

\subsection{Karakteristik Biofisik DAS Kambang}

\subsubsection{Jenis Tanah}

Berdasarkan Peta Tanah Semi Detail Kota Jambi Provinsi Jambi menurut Badan Penelitian dan Pengembangan Pertanian (BBSDLP) Kementerian Pertanian tahun 2016, jenis tanah di DAS Kambang didominasi kambisol dan sebagian kecil podsolik. Peta ini kemudian dianalisis dengan software Arc gis sehingga didapat jenis tanah kambisol pada DAS Kambang meliputi lahan seluas 434,705 ha. Sedangkan luas lahan DAS Kambang yang diliputi tanah podsolik yaitu 0,186 ha $(0,0428 \%)$.

Tabel 1. Jenis Tanah pada DAS Kambang

\begin{tabular}{llll}
\hline No & Jenis Tanah & Luas (ha) & Persentase (\%) \\
\hline 1 & Kambisol & 434,705 & 99,957 \\
2 & Podsolik & 0,186 & 0,0428 \\
Total & & 434,89 & 100 \\
\hline
\end{tabular}

Sumber: BBSDLP, 2016

\subsubsection{Penggunaan Lahan}

Penggunaan lahan pada tahun 2018 di DAS Kambang didominasi oleh permukiman dan semak belukar. Penggunaan lahan untuk permukiman pada tahun $2018(395,49)$ ha mengalami peningkatan dibandingkan Tahun $2013(231,46)$ ha (Tabel 2). Penambahan luasan untuk permukiman menjadi 35 $\%$ dari tahun 2013, sedangkan luasan semak belukar berkurang sampai 34\%. Diduga penggunaan lahan tersebut beralih fungsi menjadi kawasan permukiman. 
Tabel 2. Tata Guna Lahan di DAS Kambang

\begin{tabular}{ccccc}
\hline $\begin{array}{c}\text { Jenis } \\
\text { Penggunaan } \\
\text { Lahan }\end{array}$ & $\begin{array}{c}\text { Luas } \\
\text { (ha) }\end{array}$ & $\begin{array}{c}\text { Persentase } \\
(\%)\end{array}$ & $\begin{array}{c}\text { Luas } \\
\text { (ha) }\end{array}$ & $\begin{array}{c}\text { Persentase } \\
(\%)\end{array}$ \\
\hline Jalan & 6,84 & 1,6 & 7,84 & 1,8 \\
Lahan & 22,43 & 5,3 & 2,43 & 0,5 \\
Terbuka & 1,17 & 0,2 & 1,17 & 0,2 \\
Taman & 231,46 & 55,1 & 395,49 & 90,9 \\
Pemukiman & 23,39 & 1,5 & 6,39 & 1,4 \\
Pendidikan & 6,39 & 0,4 & 2,46 & 0,5 \\
Perdagangan & 1,96 & 0,1 & 0,52 & 0,1 \\
Perkantoran & 0,52 & 0,2 & 0,91 & 0,2 \\
Rumah Sakit & 0,91 & 35,2 & 17,68 & 0,40 \\
Semak & 148,08 & & 434,89 & \\
Belukar & & & ha & $100 \%$ \\
Total & 419,76 & $100 \%$ & & \\
Penggunaan & ha & &
\end{tabular}

Sumber: Hasil Analisis, 2020

\subsubsection{Kemiringan Lereng}

Berdasarkan data RTRW Kota Jambi Tahun 2013, sebagian besar $(184,37$ ha) DAS Kambang berada pada kemiringan 0-2 \%, dan seluas 158,178 ha pada kemiringan 2-8 $\%$, serta seluas 92,341 ha pada kemiringan 8-15\% (Tabel 3). Semakin besar kemiringan lereng suatu DAS semakin cepat laju debit air yang mengalir (Gani, 2016). Artinya jika terjadi hujan dengan intensitas lebat di wilayah DAS Kambang maka berpotensi menimbulkan banjir atau genangan dengan waktu yang relatif lama.

Tabel 3. Kemiringan Lereng DAS Kambang

\begin{tabular}{cccc}
\hline Kelerengan & Kelas & Luas (ha) & Persentase (\%) \\
\hline $0-2 \%$ & Datar & 184,37 & 0,42 \\
$2-8 \%$ & Bergelombang & 158,178 & 0,36 \\
$8-15 \%$ & Landai & 92,341 & 0,21 \\
\multicolumn{2}{c}{ Jumlah } & 434,89 & 100 \\
\hline
\end{tabular}

Sumber: Bappeda Kota Jambi, 2013

\subsubsection{Ketinggian Tempat}

Kondisi topografi di Kota Jambi pada umumnya berbentuk dataran sampai bergelombang dengan ketinggian berkisar antara 0-60 meter di atas permukaan laut (BPS Kota Jambi, 2019). Berdasarkan peta kontur, DAS Kambang berada pada ketinggian antara 10-50 meter di atas permukaan laut (dpl). Sebagian besar wilayah DAS Kambang berada pada ketinggian 28 meter dpl yang rata-rata terdapat di Kelurahan Simpang III Sipin. Ketinggian antara 40-50 meter dpl terletak di Kelurahan Simpang III Sipin (Kecamatan Kotabaru). Sedangkan ketinggian wilayah 10-20 meter terletak di Kecamatan Telanaipura.

\subsubsection{Kualitas Air}

Berdasarkan data Dinas Lingkungan Hidup Kota Jambi dari tahun 2015 sampai tahun 2019 diketahui bahwa kualitas air sungai di bagian hulu DAS Kambang tidak memenuhi standar PP. No. 82 Tahun 2002 Tentang Pengelolaan Kualitas Air dan Pengendalian Pencemaran Air. Pengambilan sampel untuk kualitas air diambil di bagian hulu dan hilir sungai. Di bagian hulu yaitu di Jl. Sunan Giri (hulu I) dan di Jl. Ir.H.Juanda (hulu II) yang ditunjukkan pada Tabel 4, sedangkan bagian hilir (Tabel 5) diambil di Jl. Siwabessy Buluran.

Berbeda dengan kualitas air di bagian hulu, kualitas air Sungai Kambang di bagian hilir parameter yang melebihi baku mutu, nilainya cenderung lebih kecil dari bagian hulu. Hanya saja pada tahun 2017, nilai COD dan BOD cukup besar. PH pada air di setiap tahun juga berada pada baku mutu yang dizinkan. Secara umum, kondisi kualitas air di bagian hilir lebih baik dibandingkan hulu, hal ini dapat disebabkan oleh berbagai faktor, antara lain :

1. Pengambilan sampel kualitas air diambil pada bulan (musim) hujan sehingga dimungkinkan adanya pengenceran oleh air.

2. Pengenceran oleh air dimungkinkan sudah terjadi karena debit air di bagian hilir lebih banyak.

Berdasarkan informasi yang didapat saat melakukan wawancara ringan di DLH Kota Jambi, bahwa tidak ada treatment yang dilakukan pada air sungai Kambang baik di hulu maupun di hilir. Penambahan zat kimia dilakukan hanya pada sampel kualitas air yang diambil. Hal ini untuk mengawetkan kondisi sampel sehingga dapat dianalisis di laboratorium.

Tabel 4. Kualitas Air Sungai Kambang Bagian Hulu Tahun 2015-2019

\begin{tabular}{|c|c|c|c|c|c|c|}
\hline Parameter & Baku Mutu & Tahun 2015 & Tahun 2016 & Tahun 2017 & Tahun 2018 & Tahun 2019 \\
\hline \multicolumn{7}{|c|}{ Hulu I } \\
\hline $\mathrm{pH}$ & $6,0-9,0$ & 6,3 & 6,45 & 5,733 & 6,22 & 6,80 \\
\hline Zinc (Zn) & 0,05 & 0,08 & 0,03 & 0,133 & 0,21 & 0,90 \\
\hline DO & $>4$ & 2,355 & 1,245 & 1,570 & 2,15 & 1,91 \\
\hline COD & 25 & 44 & 34 & 79,200 & 52,84 & 36,60 \\
\hline BOD5 & 3 & 34 & 16 & 33,000 & 17,88 & 21,14 \\
\hline Phosphate(PO4) & 0,2 & 0,57 & 0,835 & 0,540 & 0,61 & 0,52 \\
\hline \multicolumn{7}{|c|}{ Hulu II } \\
\hline $\mathrm{pH}$ & $6,0-9,0$ & 6,45 & 6,225 & 5,8 & 5,96 & 6,58 \\
\hline Zinc (Zn) & 0,05 & 0,11 & 0,03 & 0,133 & 0,17 & 0,22 \\
\hline DO & $>4$ & 2,9 & 2,2 & 2,953 & 2,73 & 1,67 \\
\hline COD & 25 & 245 & 71,75 & 60,433 & 34,17 & 37,20 \\
\hline BOD5 & 3 & 75,5 & 56 & 28,333 & 13,08 & 16,16 \\
\hline Phosphate(PO4) & 0,2 & 1,54 & 0,835 & 0,640 & 0,35 & 0,35 \\
\hline
\end{tabular}

Sumber: Dinas Lingkungan Hidup Kota Jambi, 2019 
Tabel 5. Kualitas Air Sungai Kambang Bagian Hilir Tahun 2015-2019

\begin{tabular}{ccccccc}
\hline Parameter & Baku Mutu & Tahun 2015 & Tahun 2016 & Tahun 2017 & Tahun 2018 & Tahun 2019 \\
\hline Zinc (Zn) & 0,05 & 0,055 & 0,03 & 0,10 & 0,17 & 0,24 \\
DO & $>4$ & 3,095 & 2,7025 & 3,89 & 4,33 & 3,14 \\
COD & 25 & 28 & 29,5 & 60,03 & 27,60 & 25,18 \\
BOD5 & 3 & 22 & 21,75 & 30,00 & 7,05 & 11,64 \\
Phosphate(PO4) & 0,2 & 0,675 & 0,7325 & 0,35 & 0,27 & 0,42 \\
\hline
\end{tabular}

Sumber: Dinas Lingkungan Hidup Kota Jambi, 2019

\section{Kesimpulan}

Berdasarkan hasil penelitian, dapat disimpulkan sebagai berikut:

1. Analisis morfometri DAS Kambang menunjukkan bahwa DAS Kambang memiliki bentuk memanjang dengan luas 434,89 Ha dengan kerapatan sungai sedang (mendekati rendah). DAS Kambang memiliki pola aliran dendritik. Kondisi morfometri tersebut menjadikan DAS Kambang tidak rawan banjir, tetapi jika terjadi hujan dengan intensitas lebat dan waktu yang lama maka akan rawan terjadi genangan.

2. Aspek biofisik DAS Kambang menunjukkan terjadi perubahan yang signifikan pada penggunaan lahan. Berdasarkan kemiringan lereng dan ketinggian tempat, DAS Kambang berpotensi rawan terjadi genangan dengan waktu yang cukup lama. Jenis tanah di DAS Kambang didominasi oleh Kambisol $(99,957 \%)$. Kualitas air pada sungai menunjukkan adanya beberapa parameter yang tidak sesuai baku mutu (PP Nomor 82 Tahun 2002).

3. Karakter DAS Kambang berdasarkan analisis morfometri dan aspek biofisik menunjukkan bahwa DAS Kambang rawan terjadi genangan. Sehingga di masa yang akan datang peruntukkan DAS Kambang dapat memperhatikan karakter DAS Kambang.

\section{Daftar Pustaka}

Andini, M. (2019). Kajian Karakteristik Biofisik Sub Daerah Aliran Sungai (DAS) Limau Manis untuk Ketersediaan Air Berkelanjutan (Doctoral dissertation, Universitas Andalas).

Budiarti, W., Gravitiani, E., \& Mujiyo, M. (2018). Analisis Aspek Biofisik dalam Penilaian Kerawanan Banjir di Sub DAS Samin Provinsi Jawa Tengah. Jurnal Pengelolaan Sumberdaya Alam dan Lingkungan (Journal of Natural Resources and Environmental Management), 8(1), 96-108.

Fuady, Z. (2013). Tinjauan Daerah Aliran Sungai Sebagai Sistem Ekologi dan Manajemen Daerah Aliran Sungai. JURNAL LENTERA, 6(1).

Kehutanan, D., \& Air, K. S. (2010). Kajian model pengelolaan daerah aliran sungai (DAS) terpadu. Kementerian Kehutanan, Jakarta.

Kodoatie, R. J., \& Sjarief, R. (2010). Tata Ruang Air. Penerbit Andi.

Lexy, J. M. (2002). Metode Penelitian Kualitatif. Bandung: Rosda Karya.

Arikunto, S. (2003). Prosedur Penelitian Suatu Praktek. Jakarta: Bina Aksara, 3.

Suganda, E., Atmodiwirjo, P., \& Yatmo, Y. A. (2011). Pengelolaan lingkungan dan kondisi masyarakat pada wilayah hilir sungai. Hubs-Asia, 10(1).
Sugiyono, P. (2011). Metodologi Penelitian Kuantitatif Kualitatif Dan $R \& D$. Bandung: Alpabeta.

Suripin. 2004. Sistem Drainase Perkotaan Yang Berkelanjutan. Yogyakarta; Andi Offset.

Sutapa, I. W. Studi Pengaruh dan Hubungan Bentuk DAS Terhadap Parameter Hidrograf Satuan Sintetik. SMARTek, 4(4).

Wesli. 2008. Drainase Perkotaan. Yogyakarta : Graha Ilmu. 